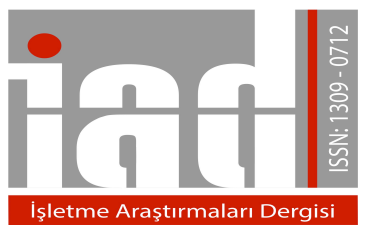

Journal Of

Business Research

Turk

www.isarder.org

\title{
Analysis of The Factors Affecting The Capital Structure of Oil Exploration And Production Companies: Comparative Analysis of TP And The Five Major Oil Exploration And Production Companies in The World
}

\author{
Mehmet ARSLAN \\ Gazi University \\ College of Banking and Insurance \\ Ankara, Turkey \\ meharsster@gmail.com
}

\author{
Mustafa Fatih BOZ \\ Turkish Petroleum \\ Ankara, Turkey \\ mfatihboz@hotmail.com
}

\begin{abstract}
Oil and gas companies are still the most powerful and profitable companies in the world. Knowing the factors that affect the preferences for forming a capital structure of such a critical sector will provide a substantial contribution to the field of capital structur theory which is understated in thef literature. Besides, determining capital structure composition and financing decisions of the oil and gas companies are important issues for national and international investors who are considering to invest in the oil and gas sector, for suppliers providing services to the sector and for banks providing funds to the sector. In this context, for analyzing the factors affecting the capital structures of EXXONMOBIL, BP, SHELL, PETROBRAS, LUKOIL and Turkish Petroleum (TP), linear regression and panel data regression analysis are perfomed by using the data of these companies for the years 2006-2014 (covering 36 quarter period). Empirical results revealed that capex, operating profit, risk and quick ratio have negative relation with leverage, whereas operating net cashflow-growth opportunities-size (all together forming an independent variable) has positive relation with leverage. Additionally, our empirical results mostly support the pecking order theory.
\end{abstract}

Key words: Capital structure, determinants of capital structure, panel data analysis, petroleum companies, ExxonMobil, BP, Shell, Petrobras, Lukoil, TP 


\section{Introduction}

Energy is an indispensable input for almost all the processes necessary for social life to survive. It has a critical prescription in terms of economic and political security of countries with limited geographical distribution and reserves. Economically, the oil sector is at the top of the high-risk sectors, which include high fixed capital investment and accompanying high activity and inadequate reserves. In addition, the sector is particularly influenced by the decisions of national and international regulatory agencies and institutions.

Capital structure decisions have been one of the most discussed topics in finance literature. As a whole these decisions determine the financial risk and survivability of the company. There are very few studies investigating the factors that affect the capital structure of oil companies. With this study, together with Turkish Petroleum Company (TP), which is a Turkish national oil company, International Petroleum Exploration and Production Companies from different countries, is one of the first experimental works covering a wide period of EXXONMOBIL, BP, SHELL, PETROBRAS, LUKOIL.

Oil companies are still one of the strongest and most profitable companies in the world. Estimating the factors influencing the preferences and developmental trends of a sector with such a critical prescription, capital structure, will contribute significantly to the literature, which has not been adequately addressed previously. As a result of the financial crisis that began in the US in 2008 , up to $60 \%$ reduction in oil prices and the effects on the capital structure of oil companies have been analyzed.

\section{Studies dealing with capital structure (Capital Structure Studies)}

In the last fifty years, various theories and various propositions related to these theories have been developed to explain the capital structure preferences of firms in the literature. The purpose of these theories and studies; are focused of How firms finance their activities, factors that affect financing decisions, and how to predict how financing decisions can change according to the characteristics of firms.

Brigham E. F., Gapenski L.C. And Ehrhardt M.C. (1999), until 1958, capital structure theories consisted largely of dispersed clauses made according to investor behavior rather than the appropriate statistical studies. The conceptual foundations of the concept were laid by the Franco Modigliani and Merton H. Miller $(1958,1963)$, which was awarded the Nobel Prize in 1958.

Theories that have been discussed and discussed as much as the day-to-day as a result of the expansion and stretching of these pioneering works by the authors, The Trade-off Theory; The choice between the firm's debt and equity is an approach that assumes a balance between the advantages of borrowing and the disadvantage it causes. Indeed, Stinglitz (1969), and Chen and Kim (1979) found that the probability of bankruptcy and the costs of full competition in market conditions were found.

(FH) (Pecking Order) Theory, which was developed by Steward C. Myers (1984) and Steward C. Myers and Nicholas S. Majluf (1984), based on the thesis that firms determine their capital structures based mainly on information asymmetry. Myers and Donaldson (1961) were the foundations of the work. On the other hand, ShyamSunders and Myers (1999) stated that the findings of the mature firm in an empirical study perfectly described the theories of the PO Theory. According to the theory, the 
debt rate determined by each firm will reflect the cumulative need for external financing. Brealey, R.A., Myers S.C. And Allen F. (2006), in the PO Theory, the most profitable firms generally have low debt ratios because do not need external financing.

Rajan and Zingales (1995) find that firms with high growth opportunities and profitable firms tend to have low leverage when they study the debt and equity preferences of large firms in Canada, France, Germany, Italy, Japan, the United Kingdom and the United States; Firms with large tangible assets and large firms tend to have high leverage. Frank and Goyal (2009) conducted research based on the ratio of market value of total debt assets to US firms open to the stock market during the period of 1950-2003. The results of the surveys are similar to those of Rajan and Zingales (1995).

This study reveals the importance of the most commonly used factors that affect the capital structure in the literature and the importance of the capitalization decisions of the biggest petroleum production companies in the world and the compatibility of the capital structure with the theories. This is an original work in this respect.

\section{Company-specific factors affecting capital structure}

It is possible to count firm-specific factors affecting capital structure as firm size, growth opportunities, asset structure, profitability, volatility in general. Of these factors, three (asset structure, size, profitability) are positively related to borrowing; both (Growth opportunities, volatility) are negatively related to borrowing. The Financing Hierarchy Theory revealed the negative relationship between these factors and borrowing. Bessler, W., Drobetz, W. and Kazemieh, R. (2011). These factors are;

Size; Large firms are generally more profitable and have less volatility in their earnings and can meet the higher debt ratio without increasing the likelihood of financial distress (Drobetz, W. and Fix, R., 2003, Bessler, W., Drobetz, W. and Kazemieh, R ., 2011).

Growth Opportunities; The structure of growth opportunities represented by high market value-book value ratio has a significant effect on a company's financial debt ratio. (Jensen M. C, 1986, Goyal, Lehn and Racic, 2002, Goyal, Lehn and Racic, 2002).

Asset Structure; The qualities of assets that a firm possesses are important determinants of the capital structure of the firm. (Pandey, 2010).

Profitability; According to the Balancing Theory, the financial advantage and the cost of attorney as well as the tax advantage brought by the use of debt will push more profitable firms towards a higher debt ratio. (Bessler, Drobetz and Kazemieh, (2011).

Volatility - Risk; Volatility / Risk is defined as the potential fluctuation around risk expected return in the finance literature and is measured by the standard deviation of expected returns. There is a negative relationship between volatility and debt ratio, both Balancing Theory and Financing Hierarchy Theory. (Bessler, Drobetz and Kazemieh, 2011).

Liquidity; Liquidity shows the ability of the firm to pay short-term liabilities. Except for the Finance Hierarchy Theory, the existence of a positive relationship between borrowing and liquidity was determined for high liquidity firms. 
Table 3.1. Results of Experimental Study on The Positive or Negative Relation of Capital Structure Factors Chosen With Leverage (Aothors's own scheme)

\begin{tabular}{|c|c|c|c|c|c|c|c|c|c|c|c|}
\hline & $\begin{array}{l}\text { Gómez, } \\
\text { Castro } \\
\text { and } \\
\text { Ortega } \\
(2016)\end{array}$ & $\begin{array}{l}\text { Fan, } \\
\text { Titman } \\
\text { and } \\
\text { Twite } \\
\text { (2012) }\end{array}$ & $\begin{array}{l}\text { Frank } \\
\text { and } \\
\text { Goyal } \\
(2009)\end{array}$ & $\begin{array}{l}\text { Mitto } \\
\text { and } \\
\text { Zhang } \\
(2008)\end{array}$ & $\begin{array}{l}\text { Kayhan } \\
\text { and } \\
\text { Titman } \\
(2007)\end{array}$ & $\begin{array}{l}\text { Goyal, } \\
\text { Lehn } \\
\text { and } \\
\text { Racic } \\
(2002)\end{array}$ & $\begin{array}{l}\text { Shyam, } \\
\text { Sunder } \\
\text { and } \\
\text { Myers } \\
(1999)\end{array}$ & $\begin{array}{l}\text { Rajan } \\
\text { and } \\
\text { Zingales } \\
(1995)\end{array}$ & $\begin{array}{l}\text { Jensen, } \\
\text { Solberg } \\
\text { and } \\
\text { Zorn } \\
(1992)\end{array}$ & $\begin{array}{l}\text { Titman } \\
\text { and } \\
\text { Wessel } \\
(1988)\end{array}$ & $\begin{array}{l}\text { Kim and } \\
\text { Sorensen } \\
\text { (1986) }\end{array}$ \\
\hline Size & - & + & + & + & + & + & & + & & - & \\
\hline Growth & & - & - & - & - & - & & - & & & - \\
\hline Profitability & - & - & - & $+/-$ & - & - & - & - & + & - & \\
\hline Asset Structure & - & + & + & + & + & - & + & + & + & & \\
\hline Volatility & & & & - & & & - & & - & & + \\
\hline
\end{tabular}

Note: In the figure, the relation between different capital structure factors and leverage ratio, the estimated sensitivity coefficients found as a result of different experimental studies are indicated as positive (+) or negative (-). The empty area in the Table shows that in the experimental study the leverage ratio and the factor was not tested and found to be not significant.

\subsection{Data and Methodology}

The research includes the analysis of the factors affecting the capital structure of oil exploration and production companies by using statistical methods and their financial interpretation studies. In this framework, the 36 quarters of the world's largest oil companies, EXXONMOBIL, BP, PETROBRAS, SHELL, LUKOIL and Turkey Petrollium A.O. (TP), the largest and national oil company of Turkey, were used for 2006-2014. Two of the five largest oil companies (EXXONMOBIL, PETROBRAS) were selected from the Americas and three from Europe (BP, SHELL, LUKOIL).

Research conducted; Using the financial data of the five companies and the TP, the variables are derived for testing the hypotheses determined, and the analysis of the derived variables by statistical methods is analyzed and interpreted. Statistical studies on the validity of scales suggest that the number of observations per independent variable is $30-40$. There are 36 observations per each independent variable in the study conducted.

\subsection{Limitations}

The scope of the research was chosen as the capital structure of oil exploration and production companies. Particularly one of the reasons for choosing this area is that the exploration and production activities of oil companies are homogeneous while the other activities are heterogeneous. In addition, one of the purposes of the analysis was to analyze the capital structure decisions of TP, which is the national oil company of Turkey, and to take the search and production part of the other companies. Thus the analysis was based on a comparable base.

For the test of hypotheses, the quarterly / yearly IFRS-based financial statements and the financial statements in the activity reports are based on the quarterly / yearly IFRS published at web page (or capital markets) of the five major oil companies in the sample. The financial data of the TP was obtained from the TP Department of Financial Affairs with the permission of the management of the company. Since the data of companies outside the TP are prepared in accordance with IFRS, 36 quarterly financial 
data for the analysis period of the TP for harmonization are presented in the related period US / TL T.C. The Central Bank has been converted to US dollars according to the average buying and selling rate. In addition, ACG oil sales revenues in Azerbaijan, which TP directly owns, other revenues of TP, and sales revenues are included in the analysis.

First, the financial data of the five oil companies have been restructured with the help of the distribution key in Equation 4.1 and Equation 4.2, so that the data of companies outside the TP are only exploration and production activities. As a distribution key, the net income and investment expenditures of these companies are based on the search and production activity (upstream) published for all periods. Ratios according to the weighted moving average method are determined when calculating the exploration and production activities, net income or investment amounts of the three years prior to the distribution year and the average of the three periods is determined as the distribution key for the following year. In the weighted moving average method, while allocating the highest weight to the nearest past (one period ahead), the weight of the backward prediction is reduced. (Clark, J.J., Hindelang T.J. and Pritchard R.E., 1989).

According to the net income ratio (\% epNIxi) of search and production activity (upstream), non-TP companies, income statement items, cash flow statement data, undistributed profits and dividend items paid in the current year; Market value and balance sheet items are distributed according to the ratio of the investment amount to the search and production activity (upstream) (\% epCAPxi). The weight percentage of years is used as $50 \%$ for the previous year, $30 \%$ for the previous year two years and $20 \%$ for the previous year three years. That's why the near-year data is more realistic.

Search and production activity (upstream) distribution keys are calculated as shown in the following 4.1 and 4.2 :

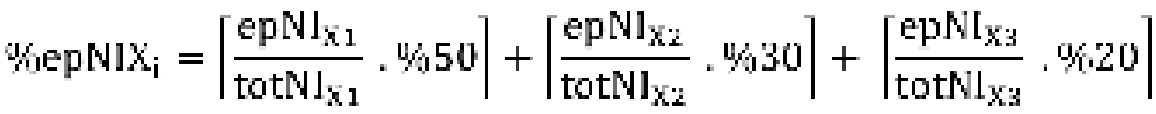

\% EpNIxi: Distribution rate according to net income of exploration and production activity (upstream)

EpNIx 1: Net income from exploration and production activity (upstream) a year ago

TotNIx1: Total net revenue a year ago

EpNIx2: Net income of exploration and production activity (upstream) of the year before two years ago

TotNIx2: Total net revenue two years ago

EpNIx3: Net income of exploration and production activity (upstream) of the year before three years ago

TotNIx3: Total net revenue three years ago

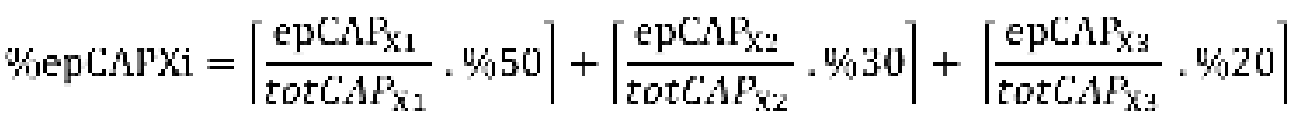

$\%$ EpCAPxi: Distribution rate by search and production activity (upstream) investment amount 
EpCAPx1: Investment amount of search and production activity (upstream) a year ago TotCAPx1: Total investment amount a year ago

EpCAPx2: Investment amount of search and production activity (upstream) two years ago

TotCAPx2: total investment amount two years ago

EpCAPx3: Investment amount of upstream search and production activity (upstream) three years ago

TotCAPx3: total investment amount three years ago

Some accounts linked to active accounts, which are in the liabilities of the company's balance sheets, are not included in the debt, including spontaneous funds (such as merchants, future income). (Brigham E.F., Gapenski L.C. and Ehrhardt M.C., 1999).

Companies outside the TP subject to analysis were publicly traded and listed on the stock exchange, so it was possible to reach the market values of the company. Because TP is not open to the public and not quoted on the stock market, there are difficulties in calculating the market value. The ratios of non-TP companies to their own "market value of exploration and production activities" were found for each analysis period, and one fifth of these ratios was assumed to be the TP market value coefficient. This coefficient is multiplied by the relevant period equity of the TP and the TP market value is calculated.

\subsection{Determination of Variables}

As a dependent variable, the ratio of the ratio of total debt to total assets to the ratio of total debt to equity is used, and the literature is searched for dependent variables that are expected to affect these variables. The variables commonly used in Table 3.1 and the authors who use these variables in their analysis are mentioned. In the literature, a group of generally accepted and predicted variables that best predict the model was chosen, which variables are shown in Table 3.2. If the debtor is a tax shield variable, it is not used in the oil exploration and production sector because of the differences in technology, country legislation and company policies.

Table 3.1. Commonly accepted variables in the literature on capital structure

\begin{tabular}{|l|l|}
\hline Variables & Literature \\
\hline \multirow{5}{*}{ Asset structure } & $\begin{array}{l}\text { Titman and Wessel (1988); Harris and Raviv (1991); Jensen, Solberg } \\
\text { and Zorn (1992); Rajan and Zingales (1995); Shyam-Sunders and } \\
\text { Myers (1999); Goyal, Lehn and Racic (2002); Sayllgan, Karabacak and } \\
\text { (2008); Karadeniz (2008); Ramadan (2009); Frank and Goyal (2009); } \\
\text { Fan, Titman and Twite (2012); Naeem (2012); Öztekin and Flannery } \\
\text { (2012); Mateev, Poutziouris and Ivanov (2013); Dang (2013); Chang, } \\
\text { Chen and Liao (2014); Vătavu (2015); }\end{array}$ \\
\hline \multirow{2}{*}{ Liquidity } & $\begin{array}{l}\text { Graham (2000); Dionne and Garand (2003); Ramadan (2009); Naeem } \\
\text { (2012); Öztekin and Flannery (2012); Mateev, Poutziouris and Ivanov } \\
\text { (2013); Vătavu (2015); }\end{array}$ \\
\hline
\end{tabular}




\begin{tabular}{|c|c|}
\hline Net & $\begin{array}{l}\text { Ramadan (2009); Francis, Hasan and Sharma (2011); Mateev, } \\
\text { Poutziouris and Ivanov (2013); }\end{array}$ \\
\hline $\begin{array}{l}\text { Asset } \\
\text { profitability } \\
\text { (ROA) / } \\
\text { Equity } \\
\text { profitability } \\
\text { (ROE) / } \\
\text { Operating } \\
\text { profitability / } \\
\text { Net Profit } \\
\text { Margin }\end{array}$ & $\begin{array}{l}\text { Titman and Wessel (1988); Harris and Raviv (1991); Jensen, Solberg } \\
\text { and Zorn (1992); Rajan and Zingales (1995); Shyam-Sunders and } \\
\text { Myers (1999); Graham (2000); Goyal, Lehn and Racic (2002); Baral } \\
\text { (2004); Sayllgan, Karabacak and Küçükkocaoğlu (2006); Kayhan and } \\
\text { Titman (2007); Mittoo and Zhang (2008); Karadeniz (2008); Ramadan } \\
\text { (2009); Frank and Goyal (2009); Fan, Titman and Twite (2012); } \\
\text { Naeem (2012); Öztekin and Flannery (2012); Dang (2013); Chang, } \\
\text { Chen and Liao (2014); Reining (2015); }\end{array}$ \\
\hline $\begin{array}{l}\text { Income } \\
\text { Volatility }\end{array}$ & $\begin{array}{l}\text { Titman and Wessel (1988); Harris and Raviv (1991); Jensen, Solberg } \\
\text { and Zorn (1992); Baral (2004); Mittoo and Zhang (2008); Ramadan } \\
\text { (2009); Frank and Goyal (2009); Muradoglu and Sivaprasad } \\
\text { (2012);Dang (2013); Reining (2015); Vătavu (2015); }\end{array}$ \\
\hline Size & $\begin{array}{l}\text { Titman and Wessel (1988); Harris and Raviv (1991); Jensen, Solberg } \\
\text { and Zorn (1992); Rajan and Zingales (1995); Goyal, Lehn and Racic } \\
\text { (2002); Dionne and Garand (2003); Sayılgan, Karabacak and } \\
\text { Küçükkocaoğlu (2006); Kayhan and Titman (2007); Mittoo and Zhang } \\
\text { (2008); Karadeniz (2008); Ramadan (2009); Frank and Goyal (2009); } \\
\text { Francis, Hasan and Sharma (2011); Muradoglu and Sivaprasad (2012); } \\
\text { Naeem (2012); Öztekin and Flannery (2012); Mateev, Poutziouris and } \\
\text { Ivanov (2013); Dang (2013); Chang, Chen and Liao (2014); Reining } \\
\text { (2015); }\end{array}$ \\
\hline $\begin{array}{l}\text { Growth } \\
\text { Opportunities }\end{array}$ & $\begin{array}{l}\text { Jensen and Meckling (1976); Kim and Sorensen (1986); Titman and } \\
\text { Wessel (1988); Harris and Raviv (1991); Rajan and Zingales (1995); } \\
\text { Goyal, Lehn and Racic (2002); Kayhan and Titman (2007); Karadeniz } \\
\text { (2008); Ramadan (2009); Frank and Goyal (2009); Francis, Hasan and } \\
\text { Sharma (2011); Muradoglu and Sivaprasad (2012); Fan, Titman and } \\
\text { Twite (2012); Naeem (2012); Öztekin and Flannery (2012); Mateev, } \\
\text { Poutziouris and Ivanov (2013); Dang (2013); Chang, Chen and Liao } \\
\text { (2014); }\end{array}$ \\
\hline $\begin{array}{l}\text { Investment } \\
\text { Ratio }\end{array}$ & $\begin{array}{l}\text { Jensen, Solberg and Zorn (1992); Graham (2000); Goyal, Lehn and } \\
\text { Racic (2002); Dionne and Garand (2003); Frank and Goyal (2009); } \\
\text { Francis, Hasan and Sharma (2011); Chang, Chen and Liao (2014); }\end{array}$ \\
\hline $\begin{array}{l}\text { Non-Debt tax } \\
\text { Shield }\end{array}$ & $\begin{array}{l}\text { DeAngelo and Masulis (1980); Titman and Wessel (1988); Harris and } \\
\text { Raviv (1991); Sayllgan, Karabacak and Küçükkocaoğlu (2006); Mittoo } \\
\text { and Zhang (2008); Karadeniz (2008); Ramadan (2009); Dang (2013); }\end{array}$ \\
\hline
\end{tabular}


Table 3.2. Selected dependent and independent variables for analysis

\begin{tabular}{|c|c|c|c|}
\hline \multicolumn{2}{|c|}{ Variables } & \multirow{2}{*}{\begin{tabular}{|l} 
Code \\
TDebt/Assets
\end{tabular}} & \multirow{2}{*}{$\begin{array}{l}\text { Definition } \\
\text { Ratio of total debt to total assets }\end{array}$} \\
\hline$\overline{\bar{\theta}}$ & & & \\
\hline อัँّั & DCU & TDebt/Equity & Ratio of total debt to total equity \\
\hline \multirow{11}{*}{ 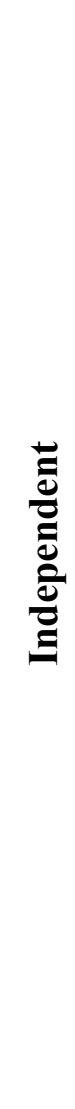 } & Fixed Asset Ratio & Tang & Ratio of fixed assets to total assets \\
\hline & Growth & TobinQ & $\begin{array}{l}\text { Ratio of company maket value to book value } \\
\text { of equity }\end{array}$ \\
\hline & $\begin{array}{l}\text { Operating } \\
\text { Profitability }\end{array}$ & OProf & Ratio of operating profit to sales \\
\hline & Net Profit Margin & NPM & Ratio of net profit to sales \\
\hline & Asset Profitability & ROA & Ratio of net profit to total assets \\
\hline & Equity Profitability & ROE & Ratio of net profit to total equity \\
\hline & $\begin{array}{l}\text { Volatility of } \\
\text { Income }\end{array}$ & Risk & $\begin{array}{l}\text { Standard deviation of variation in operating } \\
\text { profit }\end{array}$ \\
\hline & Net Cash Flow & $\mathrm{NCF}$ & $\begin{array}{l}\text { Logaritm of cash flow obtained from } \\
\text { operations }\end{array}$ \\
\hline & $\begin{array}{l}\text { Ratio of } \\
\text { investments to } \\
\text { sales }\end{array}$ & Capex & Ratio of total investment expenditures to sales \\
\hline & Size & MarketCap & $\begin{array}{l}\text { Logaritm of current market value of the } \\
\text { company }\end{array}$ \\
\hline & Liquidity & Liq & Ratio of liquid assets to short-term debts \\
\hline
\end{tabular}

\subsection{Hypotheses}

After identifying dependent and independent variables for analysis, the following eleven hypothesis statistical analyzes were carried out with the high cost and risky investments of the oil exploration and production sector, while considering the high profit margins and income volatility:

$\mathrm{H}_{1}$ : There exist a negative (reverse) relationship between the ratio of investments to sales and the use of debt (leverage).

$\mathrm{H}_{2}$ : There exist a negative (reverse) relationship between the operational profitability ratio and the use of debt (leverage).

$\mathrm{H}_{3}$ : There exist a positive (same direction) relationship between the asset-structure ratio and the use of debt (leverage).

$\mathrm{H}_{4}$ : There exist a negative (reverse) relationship between the liquidity ratio and the use of debt (leverage). 
$\mathrm{H}_{5}$ : There exist a positive (same direction) relationship between firm size and debt usage (leverage).

$\mathrm{H}_{6}$ : There exist a positive (same direction) relationship between growth opportunities and debt usage (leverage).

$\mathrm{H}_{7}$ : There is a negative (reverse) relationship between the net cash flow provided in the activities and the use of debt (leverage).

$\mathrm{H}_{8}$ : There exist a negative (reverse) relationship between the ratio of net profit to total assets (ROA) and the use of debt (leverage).

$\mathrm{H}_{9}$ : There exist a negative (reverse) relationship between the ratio of net profit to total equity (ROE) and the use of debt.

$\mathrm{H}_{10}$ : There exist a negative (reverse) relationship between income volatility (risk) and use of debt (leverage).

$\mathrm{H}_{11}$ : There exist a negative (reverse) relationship between Net Profit Margin and use of debt (leverage).

\section{FINDINGS OF THE STUDY}

\subsection{Test of Normality and Explanatory Statistical Analysis}

Since the sample size is larger than 30, the Kolmogorov Smirnov Test was applied to test whether each factor has normal distribution and whether the data are homogeneously distributed. As a result of this test, Sig. (P value / significance) are less than 0.05 which is the limit value in the statistical significance analysis, it is seen that the distributions of the examined factors/variables are not normal. dg.216, sig.0,010; The TDebt / Equity dependent variable was df.216, sig.005. The independent variables were F.216, sig 0.000, respectively. After a while, statistical observation values were normalized. After normalization of the data, explanatory statistical analyzes performed and the regression analysis conducted.

\subsection{Multiple Linear Regression Analysis}

It was tested whether the global crisis, which occurred in 2008, influenced dependent variables before switching to regression analysis between dependent and independent variables. In this context, dummy variables were instituted before and after 2008 and the relationship between this variable and the dependent variables of TDebt / Assets-TDebt / Equity was analyzed. According to the analysis result, the dummy variable and the TDebt / Assets dependent variable sig. 0.308; The TDebt / Equity dependent variable is sig. 0,546. As the significance (sig.) Value is bigger than 0.05 , the result is not statistically significant. In other words, the global crisis that emerged in 2008 determined to have no effect on dependent variables. 
Table.4.1. Multiple Linear Regression analysis of Total Debt/Total Assets for six companies combined.

\begin{tabular}{|c|c|c|c|c|}
\hline \multicolumn{5}{|c|}{ Dependent Variable: Total Debt/Total Assets } \\
\hline \multirow{7}{*}{ 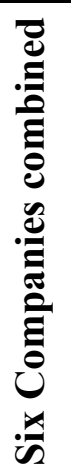 } & Independent Variable & $\mathbf{B}$ & Sig. & VIF \\
\hline & Risk & $-0,236$ & 0,000 & 1,254 \\
\hline & Liq & $-0,444$ & 0,000 & 1,294 \\
\hline & Capex & $-0,124$ & 0,038 & 1,323 \\
\hline & OProf & $-0,178$ & 0,005 & 1,504 \\
\hline & \multicolumn{4}{|c|}{$\begin{array}{c}\text { Model: Total Debt/Total Assets }=-0,11-0,236 \text { Risk - 0,444Liq - 0,124Capex - } \\
\text { 0,178OProf }\end{array}$} \\
\hline & \multicolumn{4}{|c|}{ Adjusted R square $=0,43 ; F=41,489 ;$ Sig. $=0,000$} \\
\hline
\end{tabular}

Table.4.2. Multiple Linear Regression analysis of Total Debt/Total Equity for six companies combined.

\begin{tabular}{|c|c|c|c|c|}
\hline \multicolumn{5}{|c|}{ Dependent Variable: Total Debt/Total Equity } \\
\hline \multirow{8}{*}{ 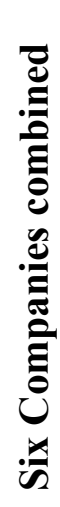 } & Independent Variable & B & Sig. & VIF \\
\hline & Risk & $-0,181$ & 0,001 & 1,254 \\
\hline & Liq & $-0,475$ & 0,000 & 1,503 \\
\hline & Capex & $-0,227$ & 0,000 & 1,378 \\
\hline & OProf & $-0,253$ & 0,000 & 2,074 \\
\hline & NCF\&TobinQ\&MarketCap & 0,167 & 0,043 & 1,964 \\
\hline & \multicolumn{4}{|c|}{$\begin{array}{c}\text { Model: Total Debt/Total Equity }=-0,002-0,181 \text { Risk - 0,475Liq - 0,227Capex - } \\
\text { 0,253OProf }+0,167 \text { NCF \&TobinQ\&MarketCap }\end{array}$} \\
\hline & \multicolumn{4}{|c|}{ Adjusted R square $=0,481 ; F=40,867 ;$ Sig. $=0,000$} \\
\hline
\end{tabular}

Multiple regression analysis was conducted with the help of SPSS software, with the dependent variables Total Debt / Total Assets and Total Debt / Total Equity, of all six companies taken together, then independent variables of all sampled companies analyzed individually. According to the multiple linear regression results of all six companies, there was a negative correlation between Capex, OProf, Risk and Liq independent variables with Total Debt / Total Assets and Total Debt / Total Equity dependent variables. On the basis of individual companies, Total Debt / Total Assets and Total Debt / Total Equity dependent variables with;

- In the TP company, there is a positive significant correlation between Tang and Liq dependent variables,

- Negative significant correlation between NCF, Risk and TobinQ dependent variables in BP company,

- In PETROBRAS, negative significant correlation between Capex, ROA \& ROE, TobinQ \& MarketCap and Liq dependent variables,

- In SHELL Company, there is a positive significant correlation between Risk and TobinQ dependent variables, 
- Negative significant correlation between NPM, NCF and Liq dependent variables in LUKOIL company,

Have been detected. In EXXONMOBIL company's data, multi- collinearity problem aroused and almost all of dependent variables and independent variables were useless.

\subsection{Panel Data Analysis}

Panel data; Horizontal cross-sectional observations belonging to units such as individuals, countries, companies, households, are gathered together at a certain period. The method of estimating economic relations with the help of panel data models created using panel data is given the name "panel data analysis". Panel data analysis; Time series and horizontal cross-sectional data observations co-exist, it allows the investigator to work with more data. In general, if the horizontal cross-sectional dimension is accidentally pulled from a large main body, random effects; If a more specific data set is concerned, it will be necessary to consider fixed effects to reduce. (Greene W. H., 2008)

For each dependent variables Total Debt / Total Assets and Total Debt / Total Equity, six companies' data were analyzed, and risk, Liq, Capex, QProf and Tang independent variables, which were found significant in the study of multiple linear regression model, were modeled and panel data analysis studies were performed separately. The classic / normal panel data model (pooled) was not chosen because all observations were considered to be homogeneous, i.e unit and / or time effects. The Hausman test (Table 4.1) was used to determine which of the fixed effects or random effects effect panel data models would be used because the data were considered to have unit and / or time effects. The H0 hypothesis was rejected because the significance level (prob.) of the random effect model was smaller than 0.05 for the Hausman test result. In other words, there is no random effect, there is a constant effect. For this reason, a fixed effect panel data analysis method (Table 4.4) was used to determine the model.

Table 4.3. Hausman test result (Dependent Variable: TDebt / Assets)

Correlated Random Effects - Hausman Test

Pool: ANALIZ01

Test cross-section random effects

\begin{tabular}{|c|c|c|c|c|}
\hline \multicolumn{2}{|l|}{ Test Summary } & Chi-Sq. Statistic & Chi-Sq. d.f. & Prob. \\
\hline \multicolumn{2}{|c|}{ Cross-section random } & 736.653642 & 5 & 0.0000 \\
\hline \multicolumn{5}{|c|}{ Cross-section random effects test comparisons: } \\
\hline Variable & Fixed & Random & Var(Diff.) & Prob. \\
\hline Risk & 0.058702 & -0.206295 & 0.001320 & 0.0000 \\
\hline Liq & 0.031567 & -0.433579 & 0.000765 & 0.0000 \\
\hline Capex & 0.001759 & -0.158006 & 0.000731 & 0.0000 \\
\hline OProf & -0.091367 & -0.174974 & 0.001238 & 0.0175 \\
\hline Tang & 0.203273 & 0.081507 & 0.000485 & 0.0000 \\
\hline
\end{tabular}


Table 4.4. Fixed effect panel data analysis results (Dependent Variable: TDebt / Assets)

Dependent Variable: TDebt/Assets

Method: Pooled Least Squares

Sample: 2006Q1 2014Q4

Included observations: 36

Cross-sections included: 6

Total pool (balanced) observations: 216

\begin{tabular}{crrrr}
\hline \hline Variable & Coefficient & Std. Error & t-Statistic & Prob. \\
\hline \hline C & 0.000760 & 0.023766 & 0.031976 & 0.9745 \\
Risk & 0.058702 & 0.046449 & 1.263788 & 0.2077 \\
Liq & 0.031567 & 0.039237 & 0.804508 & 0.4220 \\
Capex & 0.001759 & 0.040548 & 0.043388 & 0.9654 \\
OProf & -0.091367 & 0.046096 & -1.982122 & 0.0488 \\
Tang & 0.203273 & 0.035231 & 5.769649 & 0.0000 \\
Fixed Effects & & & & \\
TP & -1.407861 & & & \\
EXXON & 0.243670 & & & \\
BP & 1.073971 & & & \\
PETROBRAS & 1.091662 & & & \\
SHELL & -0.236152 & & & \\
LUKOIL & -0.765290 & & & \\
\hline \hline
\end{tabular}

Cross-section fixed (dummy variables)

\begin{tabular}{lrlr}
\hline \hline $\begin{array}{l}\text { R-squared } \\
\text { Adjusted R- }\end{array}$ & 0.879361 & Mean dependent var & $-1.44 \mathrm{E}-17$ \\
squared & 0.873476 & S.D. dependent var & 0.981196 \\
S.E. of regression & 0.349014 & Akaike info criterion & 0.782172 \\
Sum squared resid & 24.97115 & Schwarz criterion & 0.954061 \\
Log likelihood & -73.47456 & Hannan-Quinn criter. & 0.851616 \\
F-statistic & 149.4280 & Durbin-Watson stat & 0.527055 \\
Prob(F-statistic) & 0.000000 & & \\
\hline \hline
\end{tabular}

According to the results of the fixed effect panel data analysis, as shown in Table 4.2, the relationship between the dependent variable TDebt / Assets and the independent variables OProf and Tang (prob. $<0.05$ ), based on a total of 216 observations, Positive relationship between the dependent variable TDebt / Assets and the Tang independent variable (Coefficient $=0.203273$ ); However a negative relationship between the OProf independent variables have been determined (Coefficient $=-0,091367)$.

The data of TP, BP, PETROBRAS and LUKOIL have been the most influential units according to the results of TDEBt / Assets dependent variable fixed panel data analysis. It seen that, TP (Coefficient $=-1,407861$ ) and LUKOIL (Coefficient $=$ $0,765,290)$ have reverse direction; BP (Coefficient $=1.073971$ ) and PETROBRAS (Coefficient $=1.091662)$ have the same direction. In addition, the $\mathrm{R}^{2}$ value of the 
analysis is $0.873476 .87 \%$ of the dependent variable is explained by the independent variables in the model. According to the analysis results, the F-statistic value is 149,4280 and the F-statistic probability value is $p=0.00000$. These results show that the corrected $\mathrm{R}^{2}$ value is significant. (Table 4.4)

The TDebt / Assets dependent variable fixed panel data analysis can be represented by the following formula:

TDebt/hssets it

$$
\begin{aligned}
& =0,000760_{i t}-0,091367_{i t} 0^{0} \text { Prof }_{i t}+0,203273_{i t} \text { Tang }_{i t} \\
& +\varepsilon_{i t}
\end{aligned}
$$

In the above formula, $\mathrm{i}$ is the subindex unit, $\mathrm{t}$ is the subindex time, and $\varepsilon$ is the error term. In the TDebt / Assetsit model, OProf prob. $=0.0488$; Statistical significance was found at $95 \%$ and above when Tang prob $=0.0000$.

The Hausman test (Table 4.5) was also used to determine whether exist any relationship between the TDebt / Equity dependent variable for all periods of the six companies and the risk, Liq, Capex, OProf and Tang independent variables were random or fixed effect. Fixed effect panel data analysis was carried out with the assumption that there is no random effect and fixed effect when prob. value is smaller than 0.05 and the results are depicted in Table 4.6. As a result of the fixed effect panel data analysis, it was determined that the relationship between the dependent variable TDebt / Equity and the independent variables OProf and Tang (since prob. $=<0.05$ ) was compared with 216 observations of each of the six companies for 36 periods. Positive relation between TDebt / Equity dependent variable and Tang independent variable (Coefficient $=0.141473$ ); Negative correlation (Coefficient $=-0,089,204)$ between OProf independent variables has been determined.

The data of TP, BP, PETROBRAS and LUKOIL have been the most effective units according to BorcOzSer dependent variable fixed panel data analysis results. TP (Coefficient $=-1,322556$ ) and LUKOIL (Coefficient $=-0,822237$ )are in the reverse direction; BP (Coefficient $=1,252721$ ) and PETROBRAS (Coefficient $=0,819571$ ) are in the same direction. The adjusted $\mathrm{R}^{2}$ values for the analysis is 0.876564 . According to the results of the analyisis $88 \%$ variations in the dependent variables was explained by the independent variables in the model. According to the analysis results, F-statistic value is 153,6789 and $F$-statistic value is $p=0.00000$. These results show that the adjusted $\mathrm{R}^{2}$ value found to be statistically significant. (Table 4.6)

TDebt / Equity dependent variable fixed panel data analysis can be represented by the following formula:

TDebt/Equityit

$$
=0,000127_{i t}-0,089204_{i,} \text { OPlof }_{\mathrm{it}}+0,141473_{i t} \text { Tang }_{\mathrm{it}}+\varepsilon_{\mathrm{it}}
$$

In the above formula, $\mathrm{i}$ is the sub-index unit, $\mathrm{t}$ is the sub-index time, and $\varepsilon$ is the error term. In the TDebt / Equityit model, OProf probe $=0.0515$; Statistical significance was found at $95 \%$ and above when Tang probe $=0.0001$. 
Table 4.5.Hostman test results (Dependent Variable: Debt / Equity)

Correlated Random Effects - Hausman Test

Pool: ANALIZ01

Test cross-section random effects

\begin{tabular}{|c|c|c|c|c|}
\hline Test Summary & & Chi-Sq.Statistic & Chi-Sq. d.f. & Prob. \\
\hline Cross-section random & & 693.632285 & 5 & 0.0000 \\
\hline \multicolumn{5}{|c|}{ Cross-section random effects test comparisons: } \\
\hline Variable & Fixed & Random & Var(Diff.) & Prob. \\
\hline Risk & 0.013010 & -0.192372 & 0.001288 & 0.0000 \\
\hline Liq & 0.005276 & -0.432896 & 0.000746 & 0.0000 \\
\hline Capex & -0.028236 & -0.236503 & 0.000713 & 0.0000 \\
\hline Oprof & -0.089204 & -0.178703 & 0.001208 & 0.0100 \\
\hline Tang & 0.141473 & -0.033006 & 0.000473 & 0.0000 \\
\hline
\end{tabular}

Table 4.6. Fixed effect panel data analysis results (Dependent Variable: TDebt /

Dependent Variable: TDebt/Equity

\section{Equity)}

Method: Pooled Least Squares

Date: 12/16/15 Time: 18:54

Sample: 2006Q1 2014Q4

Included observations: 36

Cross-sections included: 6

Total pool (balanced) observations: 216

\begin{tabular}{crrrr}
\hline \hline Variable & Coefficient & Std. Error & t-Statistic & Prob. \\
\hline \hline C & 0.000127 & 0.023474 & 0.005410 & 0.9957 \\
Risk & 0.013010 & 0.045879 & 0.283581 & 0.7770 \\
Liq & 0.005276 & 0.038756 & 0.136125 & 0.8919 \\
Capex & -0.028236 & 0.040050 & -0.705013 & 0.4816 \\
Oprof & -0.089204 & 0.045530 & -1.959240 & 0.0514 \\
Tang & 0.141473 & 0.034799 & 4.065456 & 0.0001 \\
Fixed Effects & & & & \\
TP & -1.322556 & & & \\
EXXON & 0.216847 & & & \\
BP & 1.252721 & & & \\
PETROBRAS & 0.819571 & & & \\
SHELL & -0.144346 & & & \\
LUKOIL & -0.822237 & & & \\
\hline \hline
\end{tabular}

Cross-section fixed (dummy variables)

\begin{tabular}{lllr}
\hline \hline $\begin{array}{l}\text { R-squared } \\
\begin{array}{l}\text { Adjusted R- } \\
\text { squared }\end{array}\end{array}$ & 0.882305 & Mean dependent var & $-1.34 \mathrm{E}-17$ \\
& 0.876564 & S.D. dependent var & 0.981196
\end{tabular}




\begin{tabular}{lrll} 
S.E. of regression & 0.344728 & Akaike info criterion & 0.757464 \\
Sum squared resid & 24.36172 & Schwarz criterion & 0.929353 \\
Log likelihood & -70.80608 & Hannan-Quinn criter. & 0.826907 \\
F-statistic & 153.6789 & Durbin-Watson stat & 0.486697 \\
Prob(F-statistic) & 0.000000 & & \\
\hline
\end{tabular}

\section{Conclusions}

In order to determine the effect of the factors affecting capital structure of energy companies in the study, a relevant statistical methodology has been applied to determine factors affecting these firms' capital structures. To this end, the sampled firms; TP, EXXONMOBIL, BP, PETROBRAS, SHELL, LUKOIL were analyzed individually. When the size, growth opportunities and net cash flows of oil companies were considered as the only variable (NCF-TobinQ-MarketCap), a positive correlation was found between this variable and the debt ratio. (Adj. $\mathrm{R}^{2}=0,43 ; \mathrm{F}=41,489$; Sig. $=0,000)$ Larger companies are more likely to access credit markets, and credit costs are less costly than small ones, increasing borrowing opportunities. Analyzed companies do not have difficulty in obtaining loans on financial markets, in the case of financial or tax advantage, because they are multinational and large oil companies. It seems that the general principle for companies is "not a diminishing (decreasing), but growing company find loan" it is valid for oil companies.

The high risk of oil investments is in the opposite direction between investment expenditures (Capex) and demand for borrowing. In the case of companies alone, it was determined that only PETROBRAS had a significant and negative relationship between investment ratio and leverage values in accordance with the general outcome (Adj. $\mathrm{R}^{2}=$ 0,$546 ; F=9,429$; Sig.=0,000). Since R\&D (AR-GE;Research-Development) expenditures included in investment expenditures can not be distinguished $R \& D$ There is no comment on its use.

As a result of the linear regression analysis, no significant relationship was found between the tangible assets of the oil companies and their use of leverage. In panel data analysis, however, the same directional relationship was found between tangible asset structure (Tang) and borrowing. Panel data analysis was the most influential companies, PETROBRAS and BP, in the same direction (Adj. $\mathrm{R}^{2}=0,509 ; \mathrm{F}=13,076$; Sig. $=0,000$ )

Since the investment rate in oil investments is not constant, the liquid resources are increasing and the need for foreign resources is decreasing. In the case of company specifically, it has been found that there is a significant and negative relationship between liquidity (Liq) and borrowing between liquidity and leverage values in line with the general outcome of PETROBRAS and LUKOIL. (Adj. $\mathrm{R}^{2}=0,546 ; \mathrm{F}=9,429$ ; Sig. $=0,000-$ Adj. $R^{2}=0,776 ; F=25,263$; Sig. $=0,000$ respectively) and $\mathrm{TP}$ company has a significant and positive relationship between liquidity (Liq) and leverage values. (Adj. $\mathrm{R}^{2}=0,643 ; \mathrm{F}=13,610 ;$ Sig. $=0,000$ )

As seen in the results of linear regression and panel data analysis, the volatility in oil prices affected the profitability, decreased profitability, increased the amount of borrowing needs in order to finance investments or to meet the cash deficit. In the same period, as the oil prices increased, the operating profit (Oprof) increased and the 
leverage ratio moved downwards. This result is also reflected in the reverse relation between profitability and leverage and FH theory Compatible.

Similar to the general outcome of the oil companies, the negative relationship between profitability and leverage of the TP and SHELL companies was determined. The negative relationship between operational profitability and leverage in the panel data analysis results is highest for TP and LUKOIL companies. As a result of Lukoil's linear regression analysis, there is a same direction relationship between operational profitability (Oprof) and borrowing. (Adj. $\mathrm{R}^{2}=0,776$; $\mathrm{F}=25,263$; Sig. $=0,000$ ) This result seems to be consistent with the Trade-off and Signalling Theory.

An inverse relationship has been determined between the capital structure of the oil companies and the risk, as it is in the operating profit. As the risk increases, the borrowing decreases or the equity increases more than the debt. This result is compatible with both FH theory and Trade-off theory. The data from the oil companies also support these views (Adj. $\mathrm{R}^{2}=0,43 ; \mathrm{F}=41,489$; Sig. $=0,000$ ). In particular, it was determined that BP, LUKOIL and SHELL have a significant relationship between risk and leverage values. Similar to the results of the six oil companies, a reversal has been found between the debt ratio and risk of BP (the environmental scandal-related result of the production facility of the Mexican Gulf). According to the results of the linear regression analysis of LUKOIL company, it is determined that the negative correlation between risk and borrowing was determined, and when the data of SHELL company was taken into account, the risk and the use of leverage found to be directly proportional.

According to result of the analysis, it was determined that the oil companies continue their activities with the debt - equity composition of capital structure, but they were found to form a joint venture for search investments and prefer risk sharing. Further It was determined that market values of oil companies have decreased during and after crisis periods, while they have met their capital needs with more equity. In other words, when the data of the six companies are evaluated together, investment (Capex) and risk (risk) are inversely related to use of leverage.

Analysis of the six companies in terms of net profit margins, return on assets (ROA) and return on equity (ROE) did not yield significant results. For the PETROBRAS Company, there is a positive relationship between borrowing and net profit margin, and a negative relationship when ROA-ROE is the only variable. During the analysis period, the European Brent crude oil prices were around between 60-120 US dollars, that made the oil exploration and production investments attractive and encouraged the borrowing. With the increase in the level of PETROBRAS's borrowing, the net profit margin has increased. According to the results of the linear regression analysis of BP and LUKOIL companies, an inverse relation between the net profit margin and the use of leverage. (Adj. $\mathrm{R}^{2}=0,509 ; \mathrm{F}=13,076$; Sig. $=0,000$ - Adj. $\mathrm{R}^{2}=$ $0,776 ; \mathrm{F}=25,263 ;$ Sig. $=0,000)$

In terms of size and use of leverage Only SHELL corporations proved to have negative and statistically significant relationship. (Adj. $\mathrm{R}^{2}=0,813 ; \mathrm{F}=39,055$; Sig. $=0,000$ ) For PETROBRAS, a significant and negative relationship was found between borrowing and growth opportunities and size. This is in full agreement with the theory of $\mathrm{FH}$, which negatively predicts a relationship between borrowing and growth opportunities / size, and partial with stock market timing theory. LUKOIL has a positive 
relationship between leverage and size and growth opportunities (TobinQ-MarketCap). The LUKOIL Corporation has proved to be more consistent with the trade-off theory in terms of the positive relationship between size and use of leverage.

In a combined analysis of the six companies, no significant relationship was found between the growth opportunities (TobinQ) and the magnitude (MarketCap) variables and debt ratio. On the other hand, as a result of the analysis made on a individual basis of the company; Between growth opportunities and borrowing, for TP, BP and SHELL corporations, between size and borrowing, there is significant results for SHELL.

As a conclusion, behavior of petroleum corporations' use of leverage decreases as their capital expenditures, risk (volatility of income), liquidity and operating income increases. On the other hand, borrowing levels are rising when large oil companies, whose cash flow from the activities are increased, have growth opportunities and tangible assets increase. The results of the analysis revealed that, in terms of the tangible asset structure of oil companies, trade-off theory; In terms of volatility (risk) and size-growth opportunities; trade-of theory and finance hierarchy theory; In terms of profitability and liquidity ratio, with the Theory of Finance Hierarchy found to be relevant in explaining capital structure choice of oil corporations.

\section{REFERENCES}

Baral, Keshar J. (2004). Determinants of capital structure: A case study of listed companies of Nepal, The Journal of Nepalese Business Studies Vol. I No.1, 1-13.

Bessler, W., Drobetz, W. and Kazemieh, R. (2011). Factors Affecting Capital Structure Decisions. In Baker, H.K. and Martin, G.S. (Eds.), Capital Structure and Corporate Financing Decisions : Valuation, Strategy and Risk Analysis for Creating Long-Term Shareholder Value. Hoboken, NJ, USA: John Wiley \& SonsProQuest ebrary. Web. 19 December 2014, 23-34.

Brealey, R.A., Myers S.C. and Allen F. (2006). Corporate Finance (Eighth Edition). New York: McGraw-Hill Irwin, 493-494.

Brigham E.F., Gapenski L.C. and Ehrhardt M.C.(1999). Financial Management Theory and Practice (Ninth Edition). USA: The Dryden Press, 553-622.

Chang, C., Chen, X. and Liao, G. (2014); What are the reliably important determinants of capital structure in China?, Pasific-Basin Finance Journal 30, 87-113.

Chen, A. H. and Kim, E. H. (1979). Theories of Corporate Debt Policy A Synthesis, USA:Journal of Finance, Vol.34, No.2, 371-384.

Clark, J.J, Hindelang T.J. and Pritchard R.E. (1989). Capital Budgetting: Planning and Control of Capital Expenditures (Third Edition). USA: Prentice-Hall USQ, 1464.

Dang, Viet Anh (2013). An emprical analysis of zero-leverage firms: New evidence from the UK, International Review of Financial Analysis 30, 189-202.

DeAngelo H. and Masulis R.W.(1980), Optimal Capital Structure Under Corporate and Personal Taxation. Journal of Financial Economics 8, 3-29. 
Dionne G., and Garand M. (2003). Risk management determinants affecting firms' values in the gold mining industry: new empirical results, Economic Letters 79, 43-52.

Donaldson, Gordon. (1961). Corporate Debt Capacity: A Study of Corporate Debt Policy and the Determination of Corporate Debt Capacity. Boston: Harvard Gradute School of Business Administration.

Drobetz, W. and Fix. R. (2003). What are the Determinants of the Capital Structure? Some Evidence for Switzerland, WWZ/Department of Finance, Working Paper No.4/03, 15.

Francis, B., Hasan, I. ve Sharma, Z.(2011). Leverage and growth: Effect of stock options, Journal of Economics and Business 63, 558-581.

Frank, M.Z and Goyal V.K. (2009). Capital structure decisions: Which factors are reliably important?, Financial Management, Vol. 38, No. 1, 1-37.

Gómez, A.P., Castro, G.A. and Ortega M.F. (2016). Determinants of leverage in mining companies, empirical evidence for Latin American countries, Contaduría y Administración, Vol.61, No. 1, Mexico, 26-40.

Goyal, V.K., Lehn. K. and Racic S. (2002). Growth Opportunities and Corporate Debt Policy: The Case of the U.S. Defense Industry, The Journal of Financial Economics, Vol.64, No.1, 35-59.

Graham John R. (2000). How big are the tax benefits of debt?, The Journal of Finance Vol.55, No.5, 1901-1942.

Greene William H. (2008). Econometric Analysis (Sixth Edition). New Jersey: Pearson Education, Inc., 180-184.

International Energy Agency (2015). Key World Energy Statistics

Harris, M. and Raviv, A. (1991). The Theory of Capital Structure, The Journal of Finance, Vol. 46, No. 1 , 297-355.

Jensen, G.R., Solberg D.P. and Zorn, T.S. (1992). Simultaneous Determination of Insider Ownership, Debt and Dividend Policies, Journal of Financial and Quantitative Analysis, Vol. 27, No.2., 247-263.

Jensen, Michael C. (1986). Agency Cost of Free Cash Flows, Corporate Finance and Takeovers, American Economic Review, Vol.76, No.2, 323-339.

Jensen, M. and Meckling W.H.(1976).Theory of the Firm: Managerial Behavior, Agency Costs and Ownership Structure, Journal of Financial Economics, Vol. 3, No.4, 305-360.

Karadeniz, Erdinç (2008). Analysis of the factors that affect capital structures of Turkish Lodging Companies, Unpublished Phd dissertation, Çukurova University, Adana, 1-290.

Kayhan A. and Titman, S. (2007). Firms' histories and their capital structures, Journal of Financial Economics 83, 1-32. 
Kim, W.S. and Sorensen E.H.(1986). Evidence on the Impact of the Agency Costs of Debt on Corporate Debt Policy, The Journal of Financial and Quantitative Analysis, Vol. 21, No.2, 131-144.

Mateev, M., Poutziouris, P. and Ivanov K. (2013); On the determinants of SME capital structure in Central and Eastern Europe: A dynamic panel analysis, Research in International Business and Finance 27, 28-51.

Miller, M.H. and Modigliani, F. (1958). The Cost Capital, Corporation Finance and The Theory of Investment, American Economic Review Volume 48, 261-297.

Miller, M. H. and Modigliani, F. (1963). Corporate Income Taxes and the Cost of Capiital. A Correction, The American Economic Review, Vol. 53, No. 3 , 433443.

Miller, Merton H. (1977). Debt and Taxes, The Journal of Finance, Vol. 32, No. 2 , 261-275.

Miller, Merton H. (1988). The Modigliani-Miller Proposition after Thirty Years, Journal of Economic Perspectives Vol.2 No.4, 99-120.

Mittoo, U.R. and Zhang. Z. (2008); The capital structure of multinational corporations: Canadian versus U.S. evidence, Journal of Corporate Finance 14, 706-720.

Muradoglu, Y.G. and Sivaprasad S. (2012). Capital structure and abnormal returns, International Business Review 21, 328-341.

Myers, S. C. and Majluf, N.. (1984). Corporate Financing and Investment Decisions When Firms Have Information That Investors Do Not Have, The Journal of Financial Economics, Vol.13, 187-221.

Myers, Stewart C. (1984). Capital Structure Puzzle.The Journal of Finance , Vol.39, No.3, 575- 592.

Naeem, Shammyla (2012). Financial Structure of UK Firms: The Influence of Credit Ratings, Unpublished Phd dissertation, Business School College of Social Sciences University of Glasgow,UK, 1-302.

Öztekin, Ö. and Flannery M.J.(2012). Institutional determinants of capital structure adjustment speeds, Journal of Financial Economics 103 , 88-112.

Pandey, I.M. (2010). Financial Management (Tenth Edition). New Delhi: Vikas Publishing House Pvt. Ltd, 135-155.

Parra, Francisco. (2004). Oil Politics, A Modern History of Petroleum, London: I.B. Tauris \& Co. Ltd., 1.

Petacchi, Reining (2015). Information asymmetry and capital structure : Evidence from regulation FD, Journal of Accounting and Economics 59, 143-162.

Rajan, R.G. and Zingales L. (1995). What Do We Know about Capital Structure? Some Evidence from International Data, The Journal of Finance, Vol. 50, No. 5.,14211460.

Ramadan, Abdulhadi H. (2009). Determinants of capital structure and the firm's financial performance: An Application on the UK capital market, Unpublished Phd dissertation, University of Surrey School of Management, UK, 1-322. 
Sayılgan, G., Karabacak H. and Küçükkocaoğlu (2006). The Firm-Specific Determinants of Corporate Capital Structure: Evidence from Turkish Panel Data, Investment Management and Financial Innovations sayı:3, 125-139.

Shyam-Sunders, L. and Myers S.C.(1999). Testing static tradeoff against pecking order models of capital structure, USA: The Journal of Financial Economics, Vol.51, 219-244.

Stiglitz, Joseph E. (1969). A Re-Examination of the Modigliani-Miller Theorem, USA: Review of Economics and Statistics, Vol.59, No.5, 784-793.

Titman, S. and Wessels, R. (1988). The Determinants of Capital Structure Choice, The Journal of Finance, Vol.43, No.1, 1-19.

Vătavu, Sorana (2015). The impact of capital structure on financial performance in Romanian listed companies, Procedia Economics and Finance 32, Romania, 1314-1322. 